\title{
Brief Considerations on the Relevance of the Inter-Religious Dialogue for the Mediation of the Conflicts and the Abolition of the Religious Violence from an Orthodox Perspective
}

\author{
Stelian Manolache \\ PhD, Faculty of Orthodox Theology, University Ovidius of Constanţa, Romania, stelian81stely@yahoo.com
}

\begin{abstract}
In a globalized world, where the poverty from side of the world is in contrast with the richness of another part, where the big cultures try to put in the shadow the small cultures of the world, religion will assume as main missionary objective the research of the manner in which the ethical discourse, the spiritual values and the philanthropic actions - determinant markers of any contemporary religion - can mediate the conflicts, the disputes and the violence inspired by religion or with inter-religious connotations. We intend to present brief considerations on the capacity of the institutionalized Christian religion to fulfill, through dialogue, the ontological and social vocation for the absorption of the violence through an irenic socialphilanthropic action inspired by religion.
\end{abstract}

KEYWORDS: postmodernity, person, Christian ontology, inter-religious dialogue, religious conflict

\section{The significance and the topicality of the inter-religious dialogue}

Professor Andrei Marga (2003, 30-31). wrote that "no other awareness of the human condition has nowadays the conciliation potential of the Christianity." In fact, Christianity is, essentially, the religion of the non-violence and non-aggression (Rotaru 2014-2015, 61-63), defying the divine call for peaceful living ("...be of one mind, live in peace. And the God of love and peace will be with you" - 2Corinthians 13:11). It is the religion that, by receiving Our Saviour Jesus Christ as the Prince of Peace (Isaiah 9:6), calls continuously and programmatically to global peace ("If it is possible, as far as it depends on you, live at peace with everyone" - Romans 12:18).

The Christian message, although disseminated worldwide (A. Mc. Grew) - even if only due to the fact that globalisation (Rotaru 2014, 532-541) facilitates the quasi-universal circulation of the religious values, addresses to all ethnical, national, cultural, confessional, etc. communities, which are more and more fragmented and indifferent to the others (Hans-Georg Soefnner). Christianity tries to impregnate with its irenic teachings a world that becomes day by day a world lacking harmony and cohesion. This world is characterised by social inequity, a tough fight for material resources, extremism and radicalism, disorder and chaos (Ică \& Marani 2002, 482).

In these circumstances, the Church considers that the permanent and thorough inter-religious dialogue as a possible solution for the salvation of the irenic vocation of the man and of the human society. As father Nicolae Achimescu $(2013,395)$. wrote, the disharmony of the world "urges the Orthodoxy to appeal more to dialogue", "without betraying its own identity." The dialogue represents a continuous enrichment of relating with people of different religions, based on the love for all humans, becoming necessary, more and more, as a way of living that is absolutely necessary in a world resembling to a "global village" (Marshall McLuhan) (Tomlinson 2002, 12). Therefore, the Church will not evade from carrying its message (Rotaru 2017, 57-76.) to those who do not know Christ, because the dialogue is "the expression of a state of grace" (Achimescu 2013, 373). Even if, people as the American political scientist Samuel P. Huntington or the Catholic theologian Hans Küng highlighted mostly the capacity of the religion to socially separate, the Orthodox Church, without denying their observations, will highlight more than anything the connection of the religious beliefs with the desiderate of the reciprocal understanding. The Orthodox Church will affirm the fact that "religion does not separate us and neither brings us together unless we use it for these specific purposes" (Nicolae Achimescu). Toward all those who do not institutionally belong 
to it, as well as toward those relating to God exclusively through the natural revelation, the Church will admit, with humbleness, the possibility of the work of the Holy Spirit, with a universality lacking any exclusivism ("Where can I go from your Spirit? Where can I flee from your presence?" - Psalm 139:7) In fact, the work of the Spirit who "is in all and not absent in any being, especially in those with reason" (Sf. Maxim FR,48) transcends the visible limits of the Church. It encourages and comfort (Acts 9:31), gives advice (John 14:16), prays for us (Romans 8:27) and fights to eliminate the fake or idolatrous axiological references inserted by idols in the human consciousness, attempting to put the real God in shadow, for the reason that "that 'An idol is nothing at all in the world' and that "There is no God but one"" (1 Corinthians 8:4).

From a theological perspective, the inter-religious dialogue - a permanent and actual form of expressing the universal vocation of the Church - will have as final fundament the cosmic dimension of the Trinity's work, similar to the manner in which "resting in us, Our Saviour Jesus Christ, through the Holy Spirit, is together with His Father" (Sf. Chiril, 898). Implicitly, the dialogue of the Church with those outside it, will be developed from a Christological and pneumatological perspective, more precisely in the spirit of the cosmic involvement of the sacrifice and resurrection of the Saviour ("For since death came through a man, the resurrection of the dead comes also through a man" - 1 Corinthians 15:21), corroborated with the universality of the work of the Spirit, Who "...will teach you all things and will remind you of everything I have said to you" (John 14:26). This aspect was highlighted by theologians, many times as different in formation as Paul Evdokimov or the Protestant Stanley J. Samartha (Achimescu 2006, 31), the last one known as a supporter of the rapprochement between the important institutionalised religions. Therefore, the Church understands that the inter-religious dialogue is in connection with the will and work of God (because "nothing exists outside the will of God and without Him watching over it") (Sf. Vasile cel Mare, 176). Until one point, we only can highlight the secondary role of the human agents in the establishment of the relations required by dialogue (Coman 2005, 335-336), because "the man can do nothing by himself, without the help of God"' (1 Corinthians 3:5-9).

Beyond the Christological and pneumatological dimensions, the dialogue with those belonging to another faith presents a strong anthropological determination, based on the ontological unity of the human kind, because "from one man he made all the nations that they should inhabit the whole earth..." (Acts 17:26) Therefore, no matter their confessional positioning, the people "have as fundamental feature the image and the likeness to God" (Achimescu 2006, 53). Implicitly, the human kind will have as common ground the inclination for religiosity, the inclination to the faith in transcendence, and the vocation of relating to the sacredness. All the people have the compatibility and the similarity of their religious aspirations and expectations (Sârbu 1969, 511). On the other hand, because Jesus Christ "defeated death through His death" (St. John Chrysostom) and God ,....wants all people to be saved and to come to a knowledge of the truth" (1 Timothy 2:4), the ontological unity of the humanity is completed with a unity of destiny. Ultimately, the transcending of the present human condition, in order to overcome suffering and death, toward an eschatological finality of the world, fulfilling the man as rational being, is universal and unanimous. This process breaks all the differences and particularities of cultural, civilisation and religious belief. In fact, God-Word answered directly to the universality of the eschatological aspirations in the human mind, through the cosmic amplitude of his saving work. St. Athanasius the Great wrote: "We [the human kind] were the reason for His coming [...]. We were the reason for His incarnation. He was moved by His love for the people..." (Sf. Atanasie cel Mare, 93) As result, from the perspective of the Church, "...the pillar and foundation of the truth" (1 Timothy 3:15), the other religions will also possess pieces from the Truth embodied in the person of the Saviour (Vasilescu 1982, 411), as "echo of the primordial revelation or as effect of the action of Logos Spermatikos, followed by the coming of the perfect Logos [Jesus Christ]" (Achimescu 2006, 59-60; Rotaru 2005, 295-324). By treasuring and bringing to fruition in the religious discourse and practice some fragments of the Truth, even if in a deformed manner, the possibility of the Church to enter in dialogue with the non-Christian religions is saved. The dialogue with those of other faith requires opening, sincerity and kindness, because the one believing in Christ "must seek peace and pursue 
it" (1 Peter 3:11). The peace promised by the Saviour (John 14:27) must "rule in your hearts" (Colossians 3:15). Approaching an inter-religious dialogue, we must first bring to fruition the statute of being capable to love and to highlight all the love we can offer, because "anyone who loves God must also love their brother and sister" (1 John 4:21), excluding entirely the displaying of a pretended or authentic theological superiority (Achimescu 2006, 20-21). Due to the fact that the man of this century has the ability to recognise the human unity in nature, beyond the diversity of the hypostases, the dialogical state receives the attribute of restoring the consciousness of the human ontological communion.

The inter-religious dialogue will not be able to avoid the interaction of the doctrine content and the apologetically and/or missionary approaches. Therefore, the preservation of the dialogical state will require the avoidance of dogmatically/doctrine blockages, because all the big religions have the natural tendency to unconditionally protect the factors of their identity. In fact, the reason of the dialogue does not reside in the display of the presumed superiorities/ particular theological authenticity, but in the attentive search of the uniting elements and in their highlight, finding consensus, no matter how limited it can be. From this perspective, the Orthodox Church understands that each non-Christian religion underlines, in its own way, the manner in which the general human aspirations for finding and restoring the communion with the Creator are integrated and institutionalised (Achimescu 2006, 79). The work of the Grace, even if universal and continuous, is uneven, depending on the manner in which the believers/communities/religion relates to God, more or less affected by the ontological faults following the original sin (Achimescu 2006, 78).

\section{Violence from an Orthodox perspective}

The lack of harmony and balance, the conflict, the aggression and the violence are all conjugated with the fallen man, bearing the burden of the sin. Therefore, they are artificial and unnatural (as death also is!) in relation with the authentic humanity, as described in the Genesis 1:27 ("So God created mankind in his own image; in the image of God he created them..."). As all the other faults, violence becomes possible (and explainable) by the fact that "the fall suppressed the image of God" (Evdokimov 1996, 98) in the man, and, if not totally abolishing/perverting it, made this image transparent for the evil and capable to do the evil, in the same degree as doing the good. In essence, any passion, any evil for which a man can be blamed, shows the alienation of the human condition after the fall. Violence, as any other inclination for evil, comes together with "the garments of skin" (Genesis 3:21) - a measure for the distance of the man from his divine humanity, the fall in a state similar to the nature [...] an offence, a punishment, and a wound" (Moşoiu 2000, 152). The daily proves of violence must not deceit us; even if the persistent violence can discourage and its effects are many times tragic, violence is and remains strange to the profound man, to the man created in the image of God, with the aim to be in His likeness, because, as St. Isaac of Syria said, "the passions are not from the soul, but from something added to the soul."

By falling, "Adam did not fulfil his call; he did not know to reach the union with God and the godliness of the created world" (Losski 1990, 161). On the contrary, believing that his freedom was somehow limited by a communion with God, built on obedience, Adam deliberately rejected the "garments of light", refusing to be any more a part in the love communion of the Holy Trinity. In his disobedience to God, Adam affirmed self-sufficiency and his nature become incompatible with the Heaven ("So the Lord God banished him from the Garden of Eden ..." - Genesis 3:23), revealing the fact that "the kinship with God does not automatically mean that the man dwells on the path desired by God" (Moșoiu 2000, 158). Implicitly, Adam's nature changed and his image darkened; his horizon suddenly sank in materiality ("By the sweat of your brow you will eat your food until you return to the ground, since from it you were taken" - Genesis 3:19), losing the original spiritual amplitude. By disobedience, Adam become, ontologically speaking, another man; he became the slave of the human condition, who, starting from him, will (because ".sin entered the world through one man" - Romans 5:12), the human kind perpetuates - and will continue to perpetuate until the eschatological end - the fallen nature of the "garments of skin"; thus, we can say that, without any exception, we are "the offspring of a dark lineage" (St. Macarius of Egypt). 
Beyond all these, the (cruel) reality is that the human nature falls completely when it becomes compatible with the violence. We understand by compatibility the use of violence (and, implicitly, all the similar social behaviour), although, in essence, is not a general or inevitable aspect; it is instead only possible when the extreme narrowness of the capacity to perceive and understand make the man unable to recognise his fellow man "as partner in a dialogue of love" (Stăniloae 1996, 326). The sin brought to the man the claimed certitude of the solitary and self-sufficient individual. Adam's descendants are in the impossibility to experience the fact that "there is only one common nature for all the people" (Losski 1990, 149). The fallen man became a solitary man, who, while rediscovering his vocation for communion, builds social entities based in subjective and relative criteria. For the fallen man, estranged from God and stranger to the fellow men, the dispute, the conflict, the aggression and the violence are "means" to impose his own interests in the detriment of other interests, which are, in the end, justified in the same manner. The inner world of the fall will be completely divided; the society of the people, shallow and incongruent, will be reunited from a multitude of fragments, with perpetual tensions and unsolvable antagonisms between them. This diagnose is entirely valid for the religious violence. Cain, the son of Adam and Eve, was the first man to use violence to solve a religious dispute, because "By faith Abel brought God a better offering than Cain did..." (Hebrews 11:4). The religious violence has been accompanied the development of the civilisation and its ancestral roots are still grounded nowadays. Obviously, the particularity of the causes depends on the tendency of each religion to claim the exclusive possession of the Truth and to absolutize its own norm of faith, in the detriment of other religions. Jean Delumeau wrote: "various religions exult, each in its own language, the wisdom and the compassion, the sincerity and the humility, precious common values that nobody wants to see disappearing" (Achimescu 2013, 20). In this somehow paradoxical situation, the Church will see no more than a crash of the fragments of Truth that, unfortunately, are not able to recognise their common origin and perceive the other fragments as antinomical. This generates the temptation to use other means, including the violence, in order to impose a specific fragment of the Truth. In the same time, this is also the origin of intolerance and fanaticism, factors that, in the end, will affect the freedom (the religious freedom, in our case), which is claimed so strongly by the fallen man.

Choosing to abandon the communion with the Holy Trinity - "the structure of the supreme love" (Stăniloae 1970, 333 - 355), the man also renounced to the harmony in the relation with the other people replacing it, in a subjective and improper manner, with a monologue animated by the "selfish disobedience, pride and desire" (Stăniloae 1970, 324). Taking refuge in a strange and hostile world, invariably perceived as exterior, which transforms the love and the freedom in simple desires, the fallen man sees the violence as an extreme, but eligible solution for expressing options and reaching ideals. Once they enter the sphere of the religious beliefs and practices, the man will risk to rediscover and live again Cain's tragedy, who only received from Yahve banishment and permanent estrangement, due to his extreme gesture (Genesis 4:16-21), together with a permanent feeling of guilt (Dumea 2011, 80).

\section{The inter-religious dialogue versus religious violence from an Orthodox perspective}

The inter-religious dialogue, developed in the manner highlighted by the Christian philosopher of the religions Seiichi Yagi - with sincerity and opening, can contribute to the limitation of the confessional violence, and to that of the general violence, is already a fact for us. Once established, the inter-religious dialogue will fulfil the first step in the process of reciprocally knowing and relating, initiated by the big religions - the effective acknowledgement of the religious pluralism, of the global "religious diversity" (Paul F. Knitter). This acknowledgement, hurried by the ongoing globalisation, cannot be ignored anymore. The inter-religious dialogue will generate beneficial effects for the inter-confessional tensions, disputes and conflicts by placing all the religions of the world in "an environment of opening, trust and reciprocal responsibility", starting from the premise of the liberty of consciousness and faith as primate, because "the [religious] pluralism is naturally connected with the religious liberty" (Achimescu 2013, 511-512). In these circumstances, the dialogue will be "a modality to gradually achieve a community life, based on reciprocal knowing and understanding", affirms as an action for the "common search of 
the liberty" and as "a common effort to progress in the direction of the Truth" (Achimescu 2006, 17-18). Implicitly, it will cultivate "an attitude of love and respect for the people with another faith" (Achimescu 2006, 22) and will induce a possible reduction of the violence used to solve any differences. The responsibility of the Orthodox Church in the orientation of the inter-religious dialogue toward these coordinates is important because it possesses the Truth: "I [Christ] am the way and the truth and the life. No one comes to the Father except through me." (John 14:6). Therefore, the main foundation of the dialogue will have an Christological nature (Nicolae Achimescu), because "Christ removes us from our isolation and connect us with all our fellow men" (Achimescu 2006, 19); He is "The true light that gives light to everyone was coming into the world" (John 1:9). The incarnation of Christ gives the measure of the human unity, because it was made for "the rational people lost and ruled by death through sin" (Sf. Atanasie cel Mare, 99), in other words for the entire human kind. All the human differences disappear in Christ, because, in His theandric person, Christ represents the enhypostasis of the human nature (St. Leontius of Byzantium). In Christ, "there is neither Jew nor Gentile, neither slave nor free, nor is there male and female..." (Galatians 3:28). The inter-religious dialogue is called to value the universal character of the Word made human and the common eschatological destiny, because the sacrifice and the resurrection of the Saviour aims, implicitly, "to be put into effect when the times reach their fulfilment - to bring unity to all things in heaven and on earth under Christ" (Ephesians 1:10).

In essence, the understanding and the development of the inter-religious dialogue as a pragmatic expression of the love working for the fellow people, is equal to "a happy affirmation against chaos, as a cooperation of all the partisans of life, in their search for a better human community". Therefore, the dialogue can be put in connection with a graceful state directly derived from the work of the Holy Spirit (Achimescu 2006, 21-23), Who "... will teach you all things and will remind you of everything I have said to you" (John 14:26), especially when "few Christians know enough things on the work of God in other religions" (Wilfred Cantwell Smith). Therefore, we consider that there is normal and natural to assume techniques that are proper to the desire to limit the disputes and eliminate the inter-confessional violence in the dialogical space with the nonChristian religions.

The most basic reason is the accordance with the peace message of Jesus Christ ("Let the peace of Christ rule in your hearts, since as members of one body you were called to peace" Colossians 3:15). In fact, peace is a divine gift from the Father ("the peace of God, which transcends all understanding, will guard your hearts and your minds in Christ Jesus" - Philippians 4:7), the Son ("Now may the Lord of peace himself give you peace at all times and in every way" 2 Thessalonians 3:16) and the Holy Spirit ("the fruit of the Spirit is love, joy, peace..." - Galatians $5: 22$ ). We all must search this gift in us and put it to good work, because the eschatological salvation depends on it, for us and for those urged by us to find the peace ("Blessed are the peacemakers, for they will be called children of God" - Matthew 5:9; "Make every effort to live in peace with everyone and to be holy; without holiness no one will see the Lord" - Hebrews 12:14).

Moreover, this type of vision on the inter-religious dialogue manages to prolong and concretise the archetypal value of the Christian love. This love, united with the faith (I Petru 1:8) and the obedience to Christ-God ("Whoever has my commands and keeps them is the one who loves me. The one who loves me will be loved by my Father, and I too will love them and show myself to them." - John 14:21), is plenary expressed in loving the fellow man (Ică \& Marani 2002,19). Entering in this dialogue, the man will find himself as person, acknowledging all the others as particular hypostases of the same nature, similar to the perichoretic communion inside the Trinity (Stăniloae 1996, 277), and will be able to value his entire potential, unlike the Athenian individual or the Roman citizen, opening to the others as opening to God (Ziziaoulis 1999, 24). By recognising the natural aspect of living in communion, the person will assume the ontological unity of the creation based exclusively on the love and goodness of God (Origen, 165), created and supporting a space illuminated by grace, for living with the other, through the other and for the other. According to Father Manolache the person represents the opposition of the solitary existence and will refuse the division, the distance and the separation, perceiving the unconditional remanence of the divine image in the man as the main ground for co-existence and love for the others. By assuming the 
condition of person, the man will understand that any ethnical, cultural, civilizational or religious individualism is artificial and derails him from the real vocation for communion. The opening resulted from the quality of person will absorb all the antagonisms that fragment the humanity: ethnical and national antagonisms, because the Truth overcomes the separation between the individual and community; national and universal antagonisms, and, in the same time, religious antagonisms, due to the incontestable universality of the Saviour's call: "that all of them may be one, Father, just as you are in me and I am in you" (John 17:21).

\section{Conclusions}

If we will try to depict the areas in which, beyond the legitimate and relevant results, the contemporary inter-religious dialogue can have a pragmatic finality, then the limitation of inter-confessional misunderstandings, disputes and violence would this space. Therefore, it is normal to expect - through a continuous dialogue with the non-Christian religions, in a spirit of sincerity - a decrease of the interconfessional tensions, at least as effect of the fact that the religions discuss one with another, even if they could not identify before any common references. Acknowledging this capacity, perhaps unique, of the inter-religious dialogue, we must admit that this capacity is a result of the Christological and pneumatological content of the dialogue. Therefore, the faith of the Church in Christ, in His sacrificial death, "reconciling the world to himself in Christ" (2 Corinthians 5:19), will stimulate the preoccupations for an open dialogue, practiced as work for aspirations of good, love, peace, and harmony, which are the common values of all religions.

\section{References}

Achimescu, Nicolae. 2006. Religii în dialog (Religions in dialogue). Iasi: Trinitas Publishing House.

Achimescu, Nicolae. 2013. Religie, modernitate şi postmodernitat (Religie, modernitate şi postmodernitate). Bucharest: Trinitas Publishing House.

Biblia sau Sfânta Scriptură (Bible or Holy Scripture). 2002. Bucharest: EIBMBOR.

Coman, Constantin. 2005. "Duhul misionar al Bisericii Ortodoxe (The Missionary Spirit of the Orthodox Church)." In Church on Mission. Romanian Patriarchate at Anniversary. Bucharest: EIBMBOR.

Dumea, Claudiu. 2011. Pagini dificile din Vechiul Testament (Tough pages in the Old Testament). Iaşi: Sapientia Publishing House.

Evdokimov, Paul. 1996. Ortodoxia (Orthodoxy), translated from French by PhD Irineu Ioan Popa, Arhiereu vicar. Bucharest: EIBMBOR.

Ică, Ioan jr. \& Marani, Germano (eds.). 2002. Gândirea Socială a Bisericii. Fundamente, documente, analize, perspective (Social Thinking of the Church. Fundamentals, documents, analyzes, perspectives). Sibiu: Deisis Publishing House.

Losski, Vladimir. 1990. Teologia mistică a Bisericii de Răsărit (The mystical theology of the Eastern Church). Translation, introductory study and notes by Pr. Vasile Răducă. Bucharest: Anastasia Publishing House.

Marga, Andrei. 2003. "Modernitate, religie, cultură (Modernity, religion, culture)." In Church in the Globalization Age. Alba Iulia: The Reunification Publishing House.

Moşoiu, Nicolae. 2000. Taina prezenţei lui Dumnezeu în viaţa umană (The Mystery of God's Presence in Human Life). Piteşti-Braşov-Cluj-Napoca: Paralela 45 Publishing House.

Origen, "Despre principii (About Principles)", Book II, VI, 9, In Părinți și Scriitori Bisericești (Fathers and Church Writers) (PSB), vol. 9.

Rotaru, Ioan-Gheorghe. 2005. "Logosul şi înţelepciunea (Logos and wisdom)." In History studies of universal philosophy, coord. by Alexandru Boboc, N.I.Mariş, XIII. Bucharest: Romanian Academy Publishing House.

Rotaru, Ioan-Gheorghe. 2014. "Globalization and its effect on religion." The Journal of Freedom of Conscience, Mihnea Costoiu, Liviu-Bogdan Ciucă, Nelu Burcea (eds.), Les Arcs, France: Edition IARSIC.

Rotaru, Ioan-Gheorghe. 2014-2015. "Religious Freedom and the Spirit in Which it Should Be Defended." Liberty Today-Trends \& Attitudes, no.1-no.2, Bern, Switzerland.

Rotaru, Ioan-Gheorghe. 2017. "The mission of the Church in society." Timotheus - Theological Theological Incursions, vol. 4, no. 2, Bucharest: Universitara Publishing House.

Sârbu, C. 1969. "Poziţii principiale ale ortodocşilor faţă de celelalte religii." Ortodoxia (Orthodoxy), no. 5.

Sf. Atanasie cel Mare, cap. II, VIII. In Părinți și Scriitori Bisericești (Fathers and Church Writers), vol. 15.

Sf. Atanasie cel Mare, Tratat despre întruparea Cuvântului şi despre arătarea Lui nouă, prin trup (Treated on the Incarnation of the Word), cap. I. IV, In Părinți și Scriitori Bisericești (Fathers and Church Writers), vol. 15.

Sf. Chiril al Alexandriei. "Comentariu la Evanghelia Sfântului Ioan”, Cartea a X-a, Introd. In Părinți şi Scriitori Bisericești (Fathers and Church Writers), vol. 41. 
Sf. Vasile cel Mare. “Omilii la Hexaemeron”, omilia a IX-a, V. In Părinți și Scriitori Bisericești (Fathers and Church Writers), vol. 17.

Sf. Maxim Mărturisitorul. Răspunsuri către Talasie, 15, FR, 3.

Stăniloae, Dumitru. 1970. "Sfânta Treime. Structura supremei iubiri (The Holy Trinity. Structure of Supreme Love)." Studii Teologice (Theological Studies), no. 5 - 6.

Stăniloae, Dumitru. 1996. Teologia dogmatică ortodoxă (Orthodox dogmatic theology), ed II, vol. I, Bucharest: EIBMBOR.

Tia, Teofil. 2002. "Absorbţia violenţei: responsabilitate esenţială a eticii religioase (Absorption of Violence: The Essential Responsibility of Religious Ethics)." In Violenţa în numele lui Dumnezeu. Un răspuns creştin (Violence in the name of God. A Christian answer). Alba Iulia: Reîntregirea Publishing House.

Tomlinson, John. 2002. Globalizare şi cultură (Globalization and culture), translated by Cristina Gyurcsik. Timişoara: Amarcord Publishing House.

Vasilescu, Emilian. 1982. Istoria religiilor (History of Religions), ed. II, Bucharest: EIBMBOR.

Vasilescu, Emilian.1964. "Îndatorirea religiilor de a colabora între ele pentru binele şi propăşirea omenirii (Dedicating religions to work together for the good and prosperity of humankind)." Ortodoxia (Orthodoxy), no. 3.

Vasilescu, Emilian. 1971. "Cadrul şi perspectivele dialogului interreligios (Framework and perspectives of interreligious dialogue)." Ortodoxia (Orthodoxy), no.1.

Ziziaoulis, Ioannis. 1999. Creaţia ca euharistie (Creation as Eucharist). Bucharest: Byzantine Publishing House. 